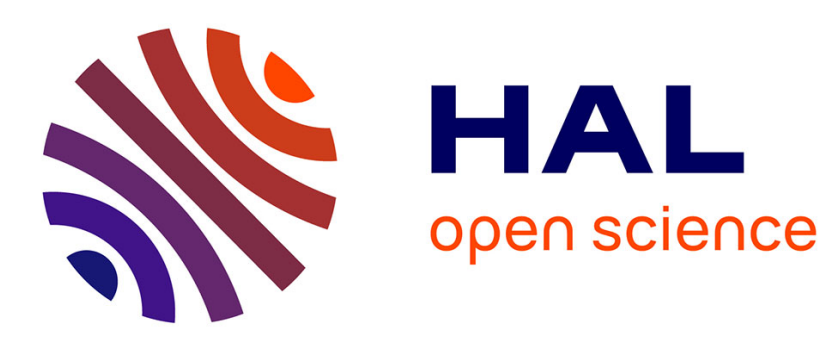

\title{
Forms and functions of SMS messages: A study of variations in a corpus written by adolescents
}

Josie Bernicot, Olga Volckaert-Legrier, Antonine Goumi, Alain Bert-Erboul

\section{To cite this version:}

Josie Bernicot, Olga Volckaert-Legrier, Antonine Goumi, Alain Bert-Erboul. Forms and functions of SMS messages: A study of variations in a corpus written by adolescents. Journal of Pragmatics, 2012, 44, pp.1701 - 1715. 10.1016/j.pragma.2012.07.009 . hal-01392578

\section{HAL Id: hal-01392578 \\ https://hal.science/hal-01392578}

Submitted on 4 Nov 2016

HAL is a multi-disciplinary open access archive for the deposit and dissemination of scientific research documents, whether they are published or not. The documents may come from teaching and research institutions in France or abroad, or from public or private research centers.
L'archive ouverte pluridisciplinaire HAL, est destinée au dépôt et à la diffusion de documents scientifiques de niveau recherche, publiés ou non, émanant des établissements d'enseignement et de recherche français ou étrangers, des laboratoires publics ou privés. 


\section{Pre-Print}

Bernicot, J., Volckaert-Legrier, O., Goumi, A. \& Bert-Erboul, A. \& (2012). Forms and functions of SMS messages: A study of variations in a corpus written by adolescents, Journal of Pragmatics, 44, 1701-1715. 10.1016/j.pragma.2012.07.009

\section{Forms and Functions of SMS Messages:}

\section{A Study of Variations in a Corpus Written by Adolescents}

Josie Bernicot ${ }^{1}$, Olga Volckaert-Legrier ${ }^{2}$, Antonine Goumi ${ }^{1}$, and Alain Bert-Erboul ${ }^{1}$

This research was supported by the French National Research Agency project ANR-08COMM-011-01 entitled "Adolescents and Computer-Mediated Writing: Prerequisites, Uses, and Learning".

Address for correspondence:

1 Université de Poitiers-CNRS, Centre de Recherches sur l'Apprentissage et la Cognition (CeRCA - MSHS, Batiment A5 - 5 rue Theodore Lefebvre, F-86000 Poitiers, France

josie.bernicot@univ-poitiers.fr; Phone: +33 (0)5.49.45.46.10 - Fax: +33 (0)5.49.45.46.16

antoninegoumi@gmail.com; alainberterboul@gmail.com

2 Université Toulouse 2 - Laboratoire PDPS Axe 4 - Psychologie des acquisitions et des apprentissages, 5 allées Antonio Machado, 31058 Toulouse Cedex 9, France

olga.volckaert-legrier@univ-tlse2.fr 


\begin{abstract}
The purpose of this research was to gain insights into SMS communication among French-speaking adolescents. We analyzed the effects of the writers' characteristics (age, gender, and SMS-messaging experience) on message length (number of characters and number of words), dialogue structure (with or without an opening and a closing), and message function (informative vs. relational). The SMS messages were produced in a realworld situation. We found differences across writers' characteristics for all the dependant variables. The commonly reported distinctions between girls and boys were mitigated. Moreover, for dialogical structure, the messages differed from those found in traditional oral and written interactions since $73 \%$ of them did not have the conventional opening-messageclosing format (the opening and/or the closing was missing). The results are discussed in terms of the specific characteristics that define the SMS register, and potentially relevant approaches to be taken in future research are addressed.
\end{abstract}

Keywords: text-messaging, register, adolescents, French language, writing, gender 


\section{Forms and Functions of SMS Messages:}

\section{A Study of Variations in a Corpus Written by Adolescents}

\section{Introduction}

Within only a few years, written communication via $\mathrm{SMS}^{1}$ has become an increasingly frequent part of our daily lives. This readily accessible technology enables asynchronous remote communication between individuals. Indeed, up until the mid-nineteenth century, letter-based communication between persons was reserved to an aristocratic or literate elite. It later became available to a larger number of individuals when compulsory education was instituted in Western countries. In 1950, oral communication by telephone became the predominant mode of interpersonal communication and remained so until text-messaging emerged as a serious competitor. The use of SMS messaging as one of the various kinds of written computer-mediated communication such as email, instant messaging, discussion forums or online help forums, and written communication on social networks has soared since the year 2000 (e.g., Facebook, Twitter) (Crystal, 2008; Danet \& Herring, 2007; Ellison, Steinfield \& Lampe, 2007; Fernandez \& Yuldashev, 2011; Herring, 1996a; Puustinen, Bernicot \& Bert-Erboul, 2011 ; Puustinen, Volckaert-Legrier, Coquin, \& Bernicot, 2009; Savas, 2011; Valkenburg \& Peter, 2009; Volckaert-Legrier, Bernicot, \& Bert-Erboul, 2009). These new modes of communication arouse both fear and fascination (Thurlow, 2006), as was the case over previous centuries upon the invention of printing, the telegraph or the telephone (Crystal, 2008). Their written forms, and particularly those of SMSes, diverge from those of traditional forms of writing. However, these phenomena are not entirely new: for example,

\footnotetext{
${ }^{1}$ SMS is the abbreviation for Short Message Service. Some synonymous terms are text-messaging and texting.
} 
abbreviations or rebus writing have been used since the very origins of writing (Crystal, 1996; Vignaux, 2003). In 2001, Crystal's presentation of text-messaging took up two pages of his book Language and the Internet, whereas he devoted an entire book to the topic in 2008.

From the scientific viewpoint, research on SMS messaging has provided new data for answering a number of questions about language acquisition and language use. The novel linguistic material found in SMSes is particularly useful in pragmatic studies, which attempt to relate linguistic productions to the communicative situation in which they are produced (Austin, 1962; Bernicot, 1994; Bernicot \& Mahrokhian, 1989; Bernicot, Comeau \& Feider, 1994; Bernicot, Laval \& Chaminaud, 2007; Grice, 1975; Herring, 2004; Noveck \& Sperber, 2004; Searle, 1969; Verschueren, 1999). The goal in the new studies is to determine the linguistic specificities of SMSing, seen as constituting a written-communication register of its own (Ravid \& Tolchinski, 2002). In this vein, Crystal (2001) stressed the importance of the concept of "language variety", which applies to oral and written language, legal and scientific language, regional particularities of a given language, literature, and also computermediated writing, including SMSing. Variations between language registers are systematic, predictable, and conventional. A university professor giving a lecture will probably not talk like a sports commentator reporting a football game. Working specifically in the area of computer-mediated communication (CMC), Herring (2004) defined the framework of Computer-Mediated Discourse Analysis (CMDA). This approach uses methods stemming from other language-focused disciplines (particularly linguistics). At the heart of CMDA is the analysis of the elements of interaction (characters, words, utterances, messages, exchanges, threads, archives, etc.). For aspects of language studied, it is important to answer the 
following questions: how do they vary depending on the context, how are they learned, and how do they change over time? A faceted classification scheme for CMDA (Herring, 2007), based upon both medium and situation factors, enables the placement of SMSes with respect to other types of computer-mediated communication. As far as medium factors are concerned, using an SMS one can send 160-character messages from a mobile phone to another computer or mobile phone located anywhere in the world, in a matter of seconds. SMS messages are used in a nearly synchronous way like traditional oral communication, while still being asynchronous like traditional writing. Among the situation factors, we generally consider the characteristics of the SMS users (for example, their gender or their experience communicating through a given medium) and the purpose-the social function, the goal of the interaction or, in other words, what the individual participants hope to accomplish through any given interaction.

Research in this area has dealt extensively with the most conspicuous feature of text messages, i.e., their peculiar orthographic forms not found in traditional writing. Most of the neographic forms inventoried so far are novel spellings resulting from puzzlegrams based on homophonic letters and numbers, phonological reductions, symbols, and acronyms (Crystal, 2008; Frehner, 2008, in French: Anis, 2007; Panckhurst, 2009; Rivière \& Licoppe, 2005). Recent studies have also looked into the relationship between SMS-specific forms, and spelling in traditional writing, during the learning period (Kemp, 2011; Wood, Jackson, Hart, Plester, \& Wilde, 2011) or in young adults (Drouin, 2011; Rosen, Chang, Erwin, Carrier \& Cheever, 2010). 
The main aim of our study was to look at several variables other than spelling, which might be just as important in characterizing SMSes written by adolescents: the length of the SMS messages, their structure, and their social function. In the following, we will present a literature review with regard to these three variables. We will then present the research questions which this study aims to answer.

\section{Literature review}

Most studies on SMS messaging have looked mainly at their orthographic content. A few studies have also analyzed measures such as SMS message length, structure, and functions.

\subsection{Message length}

SMS messages contain at most 160 characters. How do adolescents use this space? Does age have an effect? Are there differences between girls and boys? Does SMSing experience or frequency play a role?

The first studies were carried out in English, Norwegian, Swedish, German and isiXhossa in adolescents and young adults between the ages of 13 and 27 . The results varied according to the method used. In small groups of participants who were known to the researchers, message length varied between 65 and 133 characters and 14 and 22 words (Deumert \& Masinyana, 2008; Döring, Hellwig \& Klimsa, 2005; Grinter \& Eldrige, 2001; Hård af Segerstad, 2005; Thurlow \& Brown 2003). As part of a phone survey carried out with a large number of participants, message length was shorter: 29 letters and 6 words (Ling, 
2005a, 2005b). With regard to the 13- to 19-year-old age group, Ling (2005a, 2005b) emphasized that the girls produced longer messages than the boys ( 30 and 20 letters, respectively).

\subsection{Message structure}

When describing the traditional rules of oral interaction between two people, Goffman (1967) insisted upon the importance of greetings and leave-taking. These rituals are described as obligations which allow individuals to keep face (a positive social value) in a given situation. To define the interactive outline of written language, Herring (1996b) offered a basic three-part structure in which the "contentful message" is preceded by an "opening epistolary convention" followed by a "closing epistolary convention". Openings and closings are addressed directly to the interlocutor; they are discursive markers indicating how the speaker situates him or herself with respect to the addressee. Do we find this same structure in SMS interactions: the opening (greeting one another)-the message (saying what one has to say)-the closing (taking leave)? As seen by Rettie (2009) this three-phase structure is pertinent for synchronous, but not asynchronous, communication. The structure of technically asynchronous SMS messages with a quasi-synchronous functioning holds a specific study interest.

In a study carried out by Ling (2005b), only $10 \%$ of the messages contained an opening or a closing. Using an interesting method of photographing the messages on cell phones Spagnolli and Gamberini (2007) showed that, in young adults, 13\% of messages had an opening while $35 \%$ had a closing. A study focused on adolescents showed the same type of 
results. Indeed, Laursen (2005) showed that the complete opening-message-closing sequence was only very rarely used by 14 -year-old adolescents (even when taking into account interactions with a succession of 2 or 3 SMSes). In the research of Spilioti (2011), Greek-language participants transferred the messages stored in their cell phones (and exchanged among themselves over a period of several weeks) to a laptop computer. Information about the participants' SMS use was also collected. Overall, $30 \%$ of the messages included a closing. The analysis showed that closings are more present in the following circumstances: as a sign of social distance between interlocutors, as a sign of disengagement from the daily frame of contact between close friends, and as a mark of politeness in "unpleasant" situations (such closings are employed in an attempt to mitigate the potentially face-threatening act of refusing a specific request). Furthermore, closings are rare in messages which initiate interaction (in only $15 \%$ of cases).

The available studies are scarce and not analytic enough to draw any definite conclusions at this point. However, contrary to what is observed in traditional oral or written interactions, there are SMS interactions without an opening and/or a closing. This could be a specificity of SMSes as compared to other types of technically-mediated communication. It should be noted that in electronic mail, even if they are not systematic, openings and closing are much more frequent ( $50 \%$ to $100 \%$ of emails have an opening or a closing) (Bou-Franch, 2011; Volckaert-Legrier, 2007; Waldvogel, 2007).

\subsection{Message functions}

What is the purpose of SMS messages? The question of a message's purpose is linked to that of its addressee. With Japanese and French participants, Rivière and Licoppe (2005) 
showed that SMSes are mainly sent by close friends of all ages. The authors also stressed the frequency of within-family use between parents and their children, and the more limited use of texting in formal or professional situations. The majority of the exchanges studied had emotional or affective content. In cases where the SMS's function was to keep a relationship going, it did not replace the telephone call. A new mode of communication does not take the place of another, but rather fulfills different social functions (Harper, 2005). The research of Reid and Reid (2005) and de Ischii (2006) carried out in the United Kingdom and Japan, respectively, showed analogous results.

To address this topic of what SMS messages are used to say (or do), we can consider the point of view advocated in pragmatic theories, which consists of determining the writer's intention (the illocutionary goal of the message) (e.g., Searle and Vanderveken's taxonomy of speech acts, 1985). Prior studies have taken an approach consisting of defining categories of social functions that appear useful for describing the practices of users.

Past research has proposed a variety of categories for analyzing the functions of SMS messages. The only study that reported an inter-coder agreement rate (Faulkner \& Culvin, 2005) obtained a very low figure (15\%), which highlighted potential problems regarding the relevance of their categories and definitions. However, all of the studies agree on one important point: the importance of the social-relations function in text-messaging. Messages revolving around friendship maintenance are highly frequent (Deumert \& Masinyana 2008; Faulkner \& Culvin, 2005; Grinter \& Eldridge, 2001; Ling, 2005b) and for some authors, are particularly so among female adolescents (Döring et al., 2005; Kasesniemi, 2003). Thurlow and Brown's (2003) proposal to classify the functions on an axis ranging from "more informative-transactional" to "more relational and intimate" is certainly an interesting route 
for progressing on this issue. The informative-transactional category contains practical information, practical arrangements and chain letters. The relational category includes social arrangements, salutory, friendship maintenance and love- or sex-related messages. Among collected messages, $31 \%$ fell into the first category and $61 \%$ fell into the second.

\section{Research questions}

All of the studies mentioned above (except for those of Spagnolli and Gamberini in 2007, and Spilioti in 2011, described above in section 2.2.) ran across the same methodological problem: it is technically impossible to directly collect SMS messages in computer file format, which means that the participants have to copy a transient text. This situation poses the general problem of corpus reliability (the original messages are not available) and message representativeness (short, easy-to-copy messages are likely to be over-represented). So as to move past these methodological issues, we worked with a corpus containing a great number of messages created in real-life situations by a large number of writers. Furthermore, the collection method was direct and automatic, thereby avoiding all the errors and bias introduced by the manual copying of messages. Responding to an advertising campaign in the media calling them to "give your SMSes to help science", the participants sent messages stored on their cell phones to a free number which enabled the researchers to receive the messages in their original form and to organize them by participant and by date. Within this new framework, our study attempts to respond to the following questions regarding SMSes. 
1. What are the characteristics of text messages with regard to length (an index linked to the medium factors of SMSes)?

2. What are the structure and social functions of text messages (two indexes linked to the situation factors of SMSes)? In terms of the structure of the message, we were particularly interested in the linguistic markers indicating how the writer situates him or herself with respect to the addressee: the presence or absence of a salutation as a message opening and the presence or absence of leave-taking as a message closing. For the social function, we focused on the informative or relational nature of the message. We used the principle of classification from Thurlow \& Brown (2003) and adapted it to our data 2 .

3. How do SMSes vary (in length, structure and function) according to the message writer's sociolinguistic characteristics such as age, gender and SMS experience (in terms of how long and how frequently the person has been texting $\left.{ }^{3}\right)$ ?

In order to provide answers to these questions, we chose to focus on adolescence (ages 15 to 18), a period for which the little developmental information available is imprecise or contradictory, despite the fact that this is the age range during which text-messaging is used the most (Höflich \& Gebhardt, 2005). SMS messages are both inexpensive and more discreet than phone calls. It is also important to consider that the conventional writtenlanguage register develops between ages 9 and 17 (Berman, 2005), and all aspects of written language use evolve during this period (Jisa, Reilly, Verhoeven, Baruch, \& Rosado, 2002; Strömqvist, Johansson, Kriz, Ragnarsdóttir, Aisenman, \& Ravid, 2002).

\footnotetext{
${ }^{2}$ The details of our coding can be found in section 4 (4.3.3. Function indexes).

${ }^{3}$ Section 4 (4.1. Participants; 4.2. Procedure) and Appendix A provide a more detailed definition.
} 
We also took the gender of the participants into consideration. Like the original studies on oral language from the early 1900s (McCarthy, 1954), the studies in the area of computermediated writing (cf. Baron, 2004) have also pointed out differences between males and females: girls appear to use SMS messaging more often than boys, writing longer and more complex messages with more "emotional" content (Thurlow \& Poff, in press). Helsper (2010) improves this idea with a model proposing that generation determines the level of Internet use and life stage determines gender differences in Internet use. Herring (2000) has emphasized that $\mathrm{CMC}$ reproduces the same dominant male/female rapport which has been observed in traditional interactions: men control public discourse (such as forums, for example) while women tend to interact within the private sphere in smaller groups.

Additionally, it was important to consider SMSing experience. The experience (or practice) of $\mathrm{CMC}$ in general, or of another specific medium, has an influence on what the writers produce. Beach and Lundell (1998) have shown how CMC experience among 12- and 13-year-old middle school students actively engaged them in reading and writing, seen as social communication strategies. For Androutsopoulos (2006), the distinction between "novice" and "advanced" users in a variety of online communities can be made using structural characteristics or discourse pragmatics. The use of a certain medium enables the creation (in a virtual space) of an identity as well as of linguistically marked social relations.

Currently, there is very little data concerning the French language, so the results of our study will enlarge the available knowledge in this field by adding data from a new language. Surveys on French-speaking populations have pointed out the massive use of SMSes by adolescents. A study by Leo and Wolf ${ }^{4}$ (2004), and another by Samsung (2006) in Belgium, showed that $75 \%$ of the Belgian population has a mobile phone. Furthermore, $90 \%$ of the $15-$

\footnotetext{
${ }^{4}$ Leo and Wolf is a company specializing in mobile marketing.
} 
to 35-year-olds use the text-messaging function. According to the CREDOC survey conducted in France (Bigot \& Croutte, 2010), the proportion of mobile-phone users rose from $24 \%$ in 1999 to $83 \%$ in 2010 ( $84 \%$ of the 12 - to 17 -year-olds). In $2003,57 \%$ of the mobile-phone owners used the SMS function; in 2010 this figure reached $73 \%$ (97\% of the 12 - to 17 -yearolds). The average weekly number of SMS messages was 57 (182 for the 12- to 17-year-olds). Crystal (2008) and Thurlow and Poff (in press) found comparable figures for various languages (Roman alphabet-based or otherwise) and countries including the United States, the United Kingdom, Finland, Sweden, Norway, Germany, Italy, South Africa, Nigeria, New Zealand, Kuwait, Malaysia, Japan, Korea, China, Taiwan, and Hong Kong.

\section{Method}

Two research centers at the Catholic University of Leuven, Belgium, the CENTAL (Center for Automatic Language Processing) and the CELEXROM (Center for Studies on Romance Lexicons), implemented a French-speaking research project entitled "Donate Your SMS Messages to Science" ${ }^{5}$ aimed at compiling a corpus of SMS messages for research in linguistics and applied linguistics. To participate in the project, potential informants had to fill in a sociolinguistic questionnaire providing information about their characteristics. A corpus containing 30,000 SMS messages from 2,436 informants (between the ages of 12 and 73) was compiled for the project (Fairon et al., 2006). The data was collected between October and December 2004.

\subsection{Participants}

\footnotetext{
${ }^{5}$ http://www.sms4science.org/
} 
From the entire "Donate Your SMS Messages to Science" corpus, we selected 91 participants on the basis of the three following criteria: language (participants had to be French-speaking only), age (participants had to be between 15 and 18 years of age) and SMS experience (participants were either experienced or inexperienced participants). This sample was studied using three variables. Gender was used, together with age, to establish 8 subgroups $^{6}$. (cf. Table 1):

a) Age, two groups: $15-16$ years $(n=41)$ and $17-18$ years $(n=50)$

b) Gender, two groups, male $(n=42)$ and female $(n=49)$

c) SMS experience, in terms of the number of years and frequency of SMSing. We set up two contrasting experience-level groups: "experienced" $(n=60)$ and "inexperienced" ( $n=31$ ) based upon the sociolinguistic questionnaire which had been filled out by the participants (cf. section 3.2. concerning procedure and table 2 for further details).

Insert Table 1

\subsection{Procedure}

To participate in the project "Donate Your SMS Messages to Science", people had to forward SMS messages of their choice to a free phone number. It must be stressed that, particularly for an adolescent population, no matter the payment plan of the phone, the SMS donation was free of charge. The individuals were also asked to fill in a sociolinguistic

\footnotetext{
${ }^{6}$ We included in our sample all participants that satisfied our criteria except for some of the 17 - to 18 -year-olds who were experienced SMS users: in order to balance the group sizes, only the first 35 of these 49 experienced participants were included in the sample. The number of SMSes collected per participant varied between 1 and 59.
} 
questionnaire (cf. Appendix A) providing information about the informant's characteristics (language, age, gender, etc.) and experience in text-messaging. The questionnaire was addressed to a very large audience (informants between the ages of 12 and 73), did not ask questions about the type of payment plan (i.e., limited, unlimited), its price, or the person paying it. However, with regard to the adolescents we retained within our sample, we deducted, without great risk of error, that the payment plan was not unlimited (due to the date of the collection-2004), that the parents were paying for the phone service, and that the low cost, as compared to making phone calls, was one of the motivations behind the use of SMSes. As for the "experience in text-messaging" variable in our sample, the experienced participants had more than three years of text-messaging practice and claimed to send over 10 SMS messages per week (between 10 and 100). The inexperienced group had less than 3 years of text-messaging practice and claimed to send less than 10 SMS messages per week (between 0 and 10). The experience variable was therefore defined by the two items originating from the questionnaire: the length and the frequency of SMS use. Table 2 gives the number of participants in each experience group, by the number of SMS messages the participants claimed to send.

Insert Table 2

For each participant, we retained all SMSes submitted. Table 3 indicates the number of messages $^{7}$ each, for age, gender, and SMS experience level (864 messages in total).

\footnotetext{
${ }^{7}$ For the participants of both experience levels, the number of messages actually turned in was independent of the number they claimed they sent per week.
} 
Insert Table 3

\subsection{Coding}

We examined three types of message indexes: quantity indexes, structure indexes, and function indexes.

\subsubsection{Quantity indexes}

For each original message, we used the automatic counting formulas in Excel ${ }^{\circledR}$ to tally the number of characters (including spaces; the value of this index varied by definition between 1 and 160) and the number of words (defined as a letter string with a space on either side). Two examples of original messages are presented below.

(1) Example 1: 83 characters and 14 words

Original message: Euh d'accord c'est gentil! Je serai vers 7h55 devant chez toi! Bisous bonne soirée! (Uh ok, cool. l'll be outside ur place @ 7:55! Bye hava good 1).

(2) Example 2: 48 characters and 8 words

Original message: Tit mess pour savoir comment tvas depuis Itemps! (a quick message t'find out how u'v been all this time)

\subsubsection{Structure indexes}

Each message was broken down into three segments: the opening $(0)$, the message itself (M), and the closing (C). These three segments correspond to the structure defined by Herring (1996b) regarding written language and used to study the Usenet and LISTSERV messages. Our objective was to determine whether SMS users respect this three-phase 
structure: they greet each other $(\mathrm{O})$, they say what they have to say $(\mathrm{M})$, and they take leave (C). In interactions taking place via SMS, unlike traditional oral (Goffman, 1967) or written exchanges (Adam, 1998; Herring, 1996b), there are messages with no opening, no closing, or neither of the two. We defined four types of messages (see below with examples).

Message alone (M). M: Ya aussi p34 et 56. Tu dois aller chercher tt ce ki ya sur moodle en anglais. (There are pages 34 and 56 too. You have to go look for everything there is about Moodle in English.)

Opening and message (O+M). O: Salut tu vas bien? (Hi, how're you doing?) + M: G pRdu livr d1 pot. II è pa ché toi? 71 sur mart1 lutR king. (I lost a friend of mine's book. Could it be at your house? It's about Martin Luther King.)

Message and closing $(M+C)$. M: Ben tanto oui mai po $\mathrm{mtn}$ jai ecol bizoux (Well, this afternoon yes, but not now. I have school.)+ C: a tanto jtad (See you this afternoon. Love you)

Opening, message, and closing $(O+M+C)$. O: Salut $(H i)+M$ : keske tfé c soir?11srevoi kan (What are you doing tonight? When are we going to see each other again?) + C: CIAO (BYE)

A coder-agreement index for structures was defined as being equal to the number of structures coded in the same way, divided by the total number of messages coded. In all, 101 messages (chosen randomly) were coded by two coders. The mean coder-agreement index was $94 \%$. 


\subsubsection{Function indexes}

As Thurlow and Brown (2003) noted for SMSes written in English, text messages have various functions that can be classified according to two orientations: informativetransactional and relational. This was the classification we chose, by adapting it to our data. In the informative-transactional category, messages dealt with a) the exchange of practical details or requests for information or b) solidary information exchanges or requests for personal favors. During the coding process, for the sub-categories a) and b), the inter-coder agreement rate was less than 50\%: In fact, an exchange of practical details can also be interpreted as a solidary information exchange, while a request for information can be interpreted as a request for a personal favor. For this reason, we chose not to have a subcategory for the informative-transactional function. From the relational function category, we created four sub-categories: ritualized interpersonal exchanges, social arrangements, friendly relations, and love relations. One and the same message could fall into several categories or sub-categories, e.g., informative-transactional function and relational function (sub-category: love relations) or relational function (sub-category: social arrangements) and relational function (sub-category: friendly relations). The coder-agreement index for functions was calculated in the same way as the coder-agreement index for structures: the mean coder-agreement index here was $88.3 \%$. As Thurlow and Brown (2003) emphasize: "Even though, theoretically speaking, it is impossible to separate "doing sociability" from information exchange for analytical convenience, it can be revealing to compare the relative weighting of "relational" and "informational" dimensions of communication in participant responses" (p. 10). The coding was carried out in terms of the main orientation of the message. 


\section{Informative-transactional function}

Exchange of practical details but also solidary information exchange: It is clearly a favor done for the interlocutor. jtapporte le livr dmain (I'll bring you the book tomorrow).

Requests for personal favors but also resquest for information. si t as 1 2ème calculette tu pe la prendre?g oublié la mienne (If you have another calculator could you bring it? ( forgot mine.)

\section{Relational function}

Ritualized interpersonal exchanges. coment ale vous koi d9 (how are you what's new)

Social arrangements. $2 \mathrm{~m} 1$, rdv place keym a $8 \mathrm{~h}$. (tomorrow, meet at Place Keym at 8 a.m.)

Friendly relations. jsuis 2 tt coeur heureuse pr toi! Jte souhaite tt le bonheur que qq1 d'aussi exceptionnel que toi (I'm truly happy for you! I wish you all the happiness that someone as exceptional as you deserves)

Love relations. j'ai pas eu mon petit bonne nuit hier mais c'est pas grave!Tu peux pas imaginer comme tu es importante pour moi mon tit bébé!! (I didn't get my little good night last night but it's ok! You can't imagine how important you are for me my little baby!)

In the findings presented here, we did not analyze in great detail the different subcategories of each relational function category. We focused on the analysis of our study 
objective: to compare, as did Thurlow and Brown in 2003, the proportion of messages possessing an informative-transactional function with the proportion of messages possessing a relational function.

\subsection{Experimental design}

Table 4 provides a synthesis of the factors and dependent variables which we used to analyze our results. With the SMSes as the random variable, ANOVAs were performed upon the data. Results were considered significant at .05 .

Insert Table 4

\section{Results}

We examined three types of message indexes: quantity indexes, structure indexes, and function indexes.

\subsection{Quantity indexes}

The data was processed in an ANOVA with three factors: age (15-16 and 17-18 years), gender (male and female), and experience (old/frequent and recent/rare).

Number of characters (including spaces): Table 5 gives the mean number of characters as a function of age and gender. The effect of gender was significant $(F(1,856)=51.11$, $\left.p<.00001, \eta^{2}=.06\right)$, as was the age-by-gender interaction $\left(F(1,856)=24.38, p<.00001, \eta^{2}=\right.$ .03). As a whole, girls produced more characters than boys did. The difference between girls 
and boys was significant among the 15 - to 16 -year-olds $(F(1,856)=56.71, p<.00001 ; 129$ characters for girls and 82 for boys) and nonsignificant among the 17- to 18-year-olds (about 107 characters per message).

Insert Table 5

Number of words: Table 5 also gives the mean number of words as a function of age and gender. The effect of gender was significant $\left(F(1,856)=28.91, p<.00001, \eta^{2}=.03\right)$, as was the age-by-gender interaction $\left(F(1,856)=29.86, p<.00001, \eta^{2}=.03\right)$. As a whole, girls wrote more words than boys did. The difference between girls and boys was significant among the 15 - to 16 -year-olds $(F(1,856)=45.62, p<.00001 ; 24$ words for girls and 16 for boys) and nonsignificant among the 17- to 18-year-olds (about 21 words per message).

\subsection{Structure Indexes}

Four message structures were considered: message alone (M), opening and message $(\mathrm{O}+\mathrm{M})$, message and closing $(\mathrm{M}+\mathrm{C})$, and opening, message, and closing $(\mathrm{O}+\mathrm{M}+\mathrm{C})$. In all, $73 \%$ $(N=630)$ of the total number of messages $(N=864)$ did not have the traditional $O+M+C$ structure, which means that a mere $27 \%(N=234)$ of the messages did have this structure.

In cases where the structure was not traditional: structure $M$, where the message stood alone without an opening or closing, represented $23.4 \%(N=202)$ of the messages, structure $M+C$ represented almost $47 \%(N=406)$ of the messages, and structure $O+M$ had a very low frequency $(2.6 \%, N=22)$. Overall, $30 \%$ of the messages had an opening, $74 \%$ had a closing, and $77 \%$ had an opening and/or a closing. 
The structure indexes were processed in the same way as the quantity indexes. For the three most frequent structures $(M, M+C$, and $O+M+C)$, we used an ANOVA to analyze the number of occurrences per message as a function of age, gender, and experience. For type $M+C$, no factor was significant. For type $M$ (see Table 6), the effects of gender $\left(F(1,856)=7.08, p<.01, \eta^{2}=.008\right)$ and experience $\left(F(1,856)=6.52, p<.01, \eta^{2}=.007\right)$ were significant, as were the age-by-gender interaction $\left(F(1,856)=5.56, p<.01, \eta^{2}=.006\right)$ and the age-by-gender-by-experience interaction $\left(F(1,856)=12.48, p<.0004, \eta^{2}=.01\right)$. As a whole, type $M$ was produced more often by boys than by girls, and more often by experienced participants than by inexperienced ones. There was a marked difference in favor of the boys, more so at the age of 15-16 than at 17-18. Moreover, this age-by-gender interaction was present only for the experienced participants.

Insert Table 6

For structure $\mathrm{O}+\mathrm{M}+\mathrm{C}$ (see Table 6), the experience effect was significant $\left(F(1,856)=4.59, p<.03, \eta^{2}=.005\right)$, as was the age-by-gender-by-experience interaction $\left(F(1,856)=5.57, p<.01, \eta^{2}=.008\right)$. As a whole, type $\mathrm{O}+\mathrm{M}+\mathrm{C}$ was produced more often by inexperienced participants than by experienced ones. This difference in favor of inexperienced participants was present only for 15 - to 16 -year-old boys $(F(1,856)=4.99$, $p<.02)$, and 17- to 18-year-old girls $(F(1,856)=6.07, p<.01)$. 


\subsection{Function indexes}

We compared the proportion of messages that had an informative-transactional function with those that had a relational function. The data were processed in a four-factor ANOVA: three between-group factors (age, gender, and experience) and one within-group factor (message function: informative-transactional vs. relational), with the SMSes as the random variable. We concentrated on the function effect and its interactions with other factors (see Table 6). The function effect was significant $\left(F(1,856)=6.15, p<.01, \eta^{2}=.007\right)$, as were the function-by-age interaction $\left(F(1,856)=4.34, p<.03, \eta^{2}=.005\right)$, the function-bygender interaction $\left(F(1,856)=5.29, p<.02, \eta^{2}=.006\right)$. On the whole, the proportion of relational messages was greater than the proportion of informative-transactional messages; the sum of the two proportions was greater than one since the same message could have both functions. The interactions showed that the difference between the two functions was more pronounced for the 15- to 16 -year-olds than for the 17- to 18 -year-olds and for the girls than for the boys. Like Thurlow and Brown (2003), we calculated the percentages of each function out of the total number of function occurrences. We obtained $43.57 \%$ for the informative-transactional function (430 out of 987 ) and $56.43 \%$ for the relational function (557 out of 987).

\section{Discussion}

We studied a corpus of 864 SMS messages, written by 91 participants in real-world situations. The SMSes were collected using a reliable methodology that avoided transcription 
errors and over-representation of short messages. The resulting data provides answers to our research questions.

What were the characteristics of text messages from the point of view of length? How did this index vary according to the message writer's sociolinguistic characteristics?

In terms of SMS length, our results (on average, 100 characters and 20 words) are closer to those which were obtained from a small group of participants known to the researchers (Deumert \& Masinyana, 2008; Grinter \& Eldridge, 2001; Thurlow \& Brown, 2003) than to those obtained via a phone survey with a large number of participants (Ling, 2005a, 2005b). An ecological collection demonstrates that between the ages of 15 and 18, adolescents use between half and slightly more than three-fourths of the 160 characters permitted by this form of technology. Moreover, our findings provide the first evidence of changes according to age and gender: the girls' messages were indeed longer than the boys', but only among 15- and 16-year-olds. The girls and the boys seemed to have different developmental paths: between the ages of $15-16$ and $17-18$, the girls' message length (already high) stayed the same, whereas the boys' message length increased to become equivalent to that of the girls. These findings offer a different slant on Ling's study (2005a, 2005b) showing that messages produced by females were longer and more complex than those of males (between 13 and 34 years of age). However, it is difficult to compare our data with that of Ling (2005a, 2005b) due to the different method of ecological collection/survey which was used and the scale of the variations: in our study, the difference between boys and girls ranged from 80 to 130 characters, while those of Ling (2005a, 2005b) only ranged from 20 to 30. As Berko-Gleason stressed, "Most of the gender differences that do exist in boys' and girls' language are more likely to be the product of socialization and context than 
the result of innate biological differences." (p. 416). From a social point of view, the precociousness of girls may be explained by the fact that with $\mathrm{CMC}$, just as in traditional interactions, the female gender tends to put a priority on the private sphere and smaller groups (Herring, 2000). This corresponds to the reality of SMS messages which are essentially meant for close friends or family members (Ischii, 2006; Reid \& Reid, 2005; Rivière \& Licoppe, 2005). It should be mentioned that, while the differences between girls and boys disappeared around 17-18 years of age in our corpus of French-language SMSes collected in 2004, these differences still exist in other online environments (Kapidzic \& Herring, in press: popular English-language teen chat sites, collected in 2010).

What were the characteristics of text messages from the structural point of view? How did this index vary with the message writer's sociolinguistic characteristics?

Regarding the structure indexes, $73 \%$ of the messages did not follow the mandatory opening-message-closing structure of traditional oral and written exchanges. Overall, $30 \%$ of the messages had an opening, $74 \%$ had a closing. Our results are consistent with those which have already been presented by Ling (2005b), Spagnolli and Gamberini (2007) and Laursen (2005): contrary to what is observed in traditional oral or written interactions, a sizeable proportion of SMS messages exist without an opening and/or a closing. This proportion is greater than that found for another type of technically-mediated communication: the email (Bou-Franch 2011; Volckaert-Legrier, 2007; Waldvogel 2007). However, it should be pointed out that the proportion of SMS messages considered "non-canonic" varies from one study to the next. The very high proportion (90\%) which resulted from Ling's (2005b) phone survey method (where messages were dictated) is likely to cause an over-representation of short messages and thus, of messages without an opening and/or a closing. In addition, Spagnolli 
and Gamberini (2007) made a remark worth investigating-that messages without an opening or closing may be part of a conversational exchange involving several speaking turns, with an opening on the first message and a closing on the last. However, this phenomenon cannot explain why, in our study, $74 \%$ of the messages had a closing while only $30 \%$ had an opening. If Spagnolli and Gamberini's (2007) hypothesis were correct, the opening and closing percentages would be below $100 \%$, but equal. These authors emphasized that with SMSes, salutations are made using other non-verbal methods (the arrival of the message is announced by various alerts, the identity of the sender is displayed by the device) and are therefore not necessary. As the end of the exchange is not signaled by technical means, it is more often shown by a form of closing. Spilioti (2011) offers an interesting explanation regarding the presence or absence of a closing in terms of politeness. Of course, an SMS exchange is a kind of interaction that allows for the absence of a closing since it is not necessarily expected by the interlocutors. However, the presence of a closing denotes a special social situation where politeness (in terms of respecting a ritual) is necessary for the interlocutors to save face, such as in the case of social distance, disengagement from an interaction, or the refusal of a request.

With respect to prior studies, our data provides new information about the role played by the writer's characteristics: experienced 15- to 16-year-old boys generally wrote messages alone (without an opening or closing), whereas inexperienced ones wrote messages in the traditional format (opening-message-closing). The role of experience appeared in 15- to 16-year-old boys, the group which, in terms of development, took on SMS messaging the slowest. Only long-term, frequent practice enabled these boys to enter into a new dialogical structure without expressions of greeting or leave-taking, certainly linked to 
conversations involving several speaking turns (Spagnolli \& Gamberini, 2007). In sum, our data confirm that a difference does indeed exist between boys and girls. But our results indicate that this difference is mitigated on the one hand by age, and, on the other hand, by experience.

What were the characteristics of text messages from the point of view of the function? How did this index vary with the message writer's sociolinguistic characteristics?

Regarding the functions of text messages, our results are consistent with Thurlow and Brown's (2003) and with all earlier studies showing the importance of the relational function of SMSes. Moreover, for both the informative and relational functions, we validated a coding grid that gave us a high between-coder agreement rate, something that had not been done in past research. In line with our quantity indexes and structure indexes, we showed here that the informative/relational distribution varied according to the writers' characteristics: relational functions only prevailed for 15 - to 16 -year-olds, and for girls.

\section{Conclusion and limitations of the study}

Our study enabled us to show that the SMS writers' characteristics (age, gender, and SMS experience) played a role in the length, structure, and function of the text messages they wrote. Long messages were mainly produced by 15 - to 16 -year-old girls, whose messages were also largely relational. The experienced 15 - to 16 -year-old boys generally wrote messages without an opening or a closing and produced few traditional messages with an opening-message-closing structure. To draw an accurate developmental curve, future 
data collection should be extended to include both younger adolescents (ages 11-12 and 1314) and adults.

A next step could be to compare the distribution of informative (44\%) and relational (56\%) functions in SMS messages, with the distribution observed for other types of technically-mediated communication such as oral communication over the phone (land lines or cell phones), oral communication via video chatting, written communication via instant messaging, online help forums, and written communication on social networks (e.g., Facebook, Twitter).

In the long run, relating the functions of SMS messages to their linguistic characteristics (length and dialogical structure, but also orthographic forms) is likely to be that which will provide the greatest amount of insight into the SMS register.

We only analyzed a portion of the French-language corpus (Fairon et al., 2006) containing 30,000 SMS messages from 2,436 informants (between the ages of 12 and 73). A future analysis will enable us to compare the characteristics of SMSes produced by adolescents with SMSes produced by adults. A comparison between the French language and others languages will require the completion of studies in different countries using the same methodologies.

Additional research is needed to further our knowledge of the SMS register, particularly studies that take the speaking-turn sequence of the two writers into account, and ones that look at the relationship between the functions and linguistic forms of text messages. Our data bring out the complexity of the SMS register. They argue in favor of Crystal's (2001) idea of considering computer-mediated writing not as a register located somewhere between the oral and written registers, but as a register of its own that differs 
from traditional oral communication, traditional written communication, and sign language. Unlike these other three major registers, computer-mediated writing does not remain stable over time ${ }^{8}$ and currently, its extremely rapid rate of change poses a true challenge to researchers in this field.

\section{Acknowledgments}

This research was supported by the French National Research Agency project ANR-08COMM-011-01 entitled "Adolescents and Computer-Mediated Writing: Prerequisites, Uses, and Learning". Special thanks are extended to Vivian Waltz and Martha Randy for translating this paper.

\footnotetext{
${ }^{8}$ The first analyses of the francophone corpus collected as part of the sms4science project between 2004 and 2010 showed diachronic differences: e.g., the messages seemed to be shorter and shorter (Fairon, 2011).
} 


\section{Questionnaire SMS4Science}

\section{AUTHORS' PERSONAL PROFILE}

(Closed-choice questions)

- What is your age?

- What is your gender?

- What is your field of work (travel agent, librarian, salesperson, teacher, engineer, soldier, secretary, etc.)?

- What is your current level of study or highest diploma if you have finished your studies (primary, general secondary, technical secondary, superior professional secondary, etc.)?

- What is your native language (German, English, Arabic, Italian, Luxembourgish, etc.)?

- What other languages do you speak fluently (German, English, Arabic, Italian, Luxembourgish, etc.)?

- What is the postal code of your residence?

- What is your country of residence (Belgium, France, Luxembourg, etc.)?

- How many keys does your mobile phone have (min./max.)?

- Does it have a dictionary (yes/no)?

\section{AUTHORS' PRACTICE AND USE:}

(Closed-choice questions)

- How long have you been using SMS messaging?

$\square$ Less than 1 year $\square 1-3$ years $\square 3-5$ years; more than 5 years

- How may SMSes do you send on average per week?
$\square$ Less than 5
$\square 5-10$
$\square 10-20$
$20-50$

- Do you use predictive texting?

$\square$ Yes $\square$ No

- Do you understand the SMSes that you receive?

$\square$ Yes, without a problem

$\square$ Yes, but sometimes I have to "decode" them

$\square$ Yes, but with difficulty; no, they are illegible.

- Why do you use SMS messaging?

$\square$ To communicate instead of making a phone call

$\square$ As a mixture of fun and communication

$\square$ Just for fun

- How do you write your SMSes?

$\square$ Exclusively in normal French

$\square$ Mostly normal French with some SMS code

$\square$ A mixture of normal French and SMS language

$\square$ Exclusively SMS language 
- Rank the addressees of your SMSes by order of preference (never, rarely, regularly, almost daily):

Family

Friends

Colleagues

Contests/games

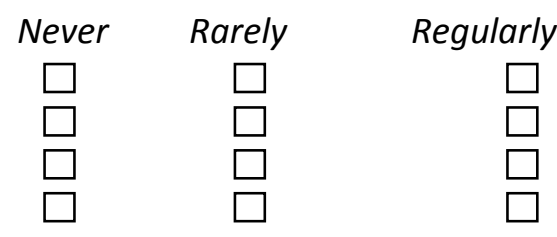

Almost daily

- What other modes or systems of communication on the Internet do you use? (never, rarely, regularly, almost daily)?

SMS from a website

Never Rarely

Regularly

Almost daily

Internet chat

Internet forums

Email

$\square \square$

$\square$
$\square$
$\square$ 


\section{References}

Adam, Jean-Michel, 1998. Les genres du discours épistolaire : de la rhétorique à l'analyse pragmatique des pratiques discursives. In J. Siess (Ed.), La lettre entre réel et fiction (pp.37-53). Paris, SEDES.

Androutsopoulos, Jannis, 2006. Introduction: Sociolinguistics and computer-mediated communication. Journal of Sociolinguistics, 23(4), 419-438.

Anis, Jacques, 2007. Neography: Unconventional spelling in French SMS text messages In : Danet, B. and Herring, S. C. (Eds), The multilingual internet: Language, culture and communication on line. New York, Oxford University Press.

Austin, John L., 1962. How to do things with words. Cambridge, Massachusetts, Harvard University Press.

Baron, Naomi S., 2004. See you online: Gender issues in college students' use of instant messaging. Journal of Language and Social Psychology, 23(4), 397-423.

Beach, Richard \& Lundell Dana Britt, 1998. Early adolescents' use of computer-mediated communication in writing and reading. In D. Reinking, M.C. McKenna, L. Labbo \& R.D. Kieffer (Eds.). Handbook of literacy and technology: transformations in a posttypographic world (pp. 93-112). Mahwah, NJ: Lawrence Erlbaum Associates.

Berko Gleason, Jean. 2001. The development of language. Needham Heights: Allyn and Bacon. (5th edition).

Berman, Ruth A., 2005. Introduction: Developing discourse stance in different text types and languages. Journal of Pragmatics, 37(2), 105-124.

Bernicot, Josie, 1994. Speech acts in young children: Vygotski's contribution. European Journal of Psychology of Education, 9, 311-320. 
Bernicot, Josie \& Mahrokhian, Alénouche, 1989. To ask and to insist after a refusal: how do 6-7-year-old children proceed ? International Journal of Psychology, n³-4, 389-407.

Bernicot, Josie, Comeau, Judith \& Feider, Helga, 1994. Dialogues between French-speaking mothers and daughters in two cultures: France and Quebec. Discourse Processes, 18, 19-34.

Bernicot, Josie, Laval, Virginie \& Chaminaud, Stéphanie, 2007. Nonliteral Language Forms in Children: In What Order Are They Acquired in Pragmatics and Metapragmatics? Journal of Pragmatics, 39, 2115-2132.

Bigot, Régis, \& Croutte, Patricia, 2010. La diffusion des technologies de l'information et de la communication dans la société française. Paris: CREDOC.

Bou-Franch, Patricia, 2011. Openings and closings in Spanish email conversations. Journal of Pragmatics, 43, 1772-1785.

Brown, Alexandra, 2002. The language and communication of SMS: An exploratory study of young adults' text-messaging. Unpublished BA dissertation, Cardiff University.

Crystal, David, 2001. Language and Internet. Cambridge, Cambridge University Press.

Crystal, David, 2008. Txtng: the gr8 db8. Oxford, Oxford University Press.

Crystal, David, 2010. The Cambridge Encyclopedia of Language (third edition). Cambridge: Cambridge University Press.

Danet, Brenda, \& Herring, Susan C., 2007. The multilingual internet: Language, culture and communication on line. New York, Oxford University Press.

Deumert, Ana, \& Masinyana, S Sibabalwe Oscar, 2008. Mobile language choices. The use of English and isiXhosa in text messages (SMS): Evidence from a bilingual South African sample. English World-Wide 29(2), 117-147. 
Döring, Nicola, Hellwig, K. \& Klimsa, Paul, 2005. Mobile Communication among Youth in Germany. In: Nyiri, K (Ed.), A Sense of Place: The Global and the Local in Mobile Communication. Wien, Passagen Verlag.

Drouin, Michelle A, 2011. College students' text messaging, use of textese and literacy skills Journal of Computer Assisted Learning, 27, 67-75 67.

Ellison, Nicole B., Steinfield, Charles, \& Lampe, Cliff, 2007. The benefits of Facebook "Friends:" Social capital and college students' use of online social network sites. Journal of Computer-Mediated Communication, 12(4), article 1. Retrieved from http://icmc.indiana.edu/vol12/issue4/ellison.html

Fairon, Cedrick, 2011. Apports du corpus SMS4science : de la correction/normalisation de SMS à la compression de texte. Retrieved 9 December 2011 from http://www.mshm.fr/IMG/pdf/Fairon_Cedrick.pdf

Fairon, Cedrick, Klein, Jean \& Paumier S, 2006. SMS pour la science. Corpus de 30.000 SMS et logiciel de consultation. Louvain-la-Neuve, Presses Universitaires de Louvain.

Faulkner, Xristine \& Culwin, Fintan, 2005. When fingers do talking: a study of text messaging. Interacting with computers, 17, 167-185.

Fernandez, Julieta \& Yuldashev, Aziz, 2011. Variation in the use of general extenders and stuff in instant messaging interactions. Journal of Pragmatics, 43, 2610-2626.

Frehner, Carmen, 2008. Email - SMS - MMS: the linguistic creativity of asynchronous discourse in the media age. Studies in Language and Communication, Vol. 58. Bern: Peter Lang.

Goffman, Erving, 1967. Interaction ritual: Essays on face-to-face behavior. Garden City, NY, Anchor. 
Grice, Paul, 1975. Logic and conversation. In: Cole, P. \& Morgan, J. (Eds), Syntax and Semantics 3: Speech Acts. New York, Academic Press.

Grinter, Rebecca E, \& Eldridge, Margery A, 2001. Y do tngrs luv 2 txt msg? In: Prinz, W., Jarke, M., Rogers, Y., Schmidt, K. \& Wulf, V. (Eds), Proceedings of the seventh European Conference on Computer-Supported Cooperative Work, Netherlands, Kluwer Academic Publishers.

Hård af Segerstad, Ylva, 2005. Language Use in Swedish Mobile Text Messaging. In: Ling, R. and Pedersen, P. E. (Eds), Mobile Communications: Re-negotiation of the social sphere. London, Springer.

Harper, Richard, Palen, Leysia, \& Taylor, Alex, (Eds.) 2005. The Inside Text. Social, Cultural and design Perspectives. Dordrecht, Netherlands, Springer.

Helsper, Ellen. J, 2010. Gendered Internet Use Across Generations and Life Stages. Communication Research, 37, 352-374.

Herring, Susan. C., 1996a. Computer-mediated Communication: Linguistic, Social and Crosscultural Perspectives. J. Benjamins, Philadelphia.

Herring, Susan. C., 1996b. Two variants of an electronic message schema. In Herring, S.C. (Ed.), Computer-Mediated Communication: Linguistic, Social and Cross-Cultural Perspectives (pp. 81-108). J. Benjamins, Philadelphia.

Herring, Susan. C., 2000. Gender differences in CMC: Findings and implications. Computer Professionals for Social Responsibility Journal (formerly Computer Professionals for Social Responsibility Newsletter), 18 (1), Retrieved 14 November 2011 from http://cpsr.org/issues/womenintech/herring/ 
Herring, Susan. C., 2004. Computer-mediated discourse analysis: An approach to researching online behavior. In Barab, S.A., Kling, R. \& Gray, J.H. (Eds.), Designing for Virtual Communities in the Service of Learning (pp. 338-376). New York: Cambridge University Press.

Herring, Susan. C., 2007. A Faceted Classification Scheme for Computer-Mediated Discourse. Language@Internet 1/2007, Retrieved 13 October 2011 from (http://www.languageatinternet.org/articles/2007)

Höflich, Joachim, \& Gebhardt, Julian, 2005. Changing Cultures of Written. Communication: Letter - E-mail -SMS. In: Harper, R., Palen, L. A. \& Taylor, A. (Eds), The inside text: Social, cultural and design perspectives on SMS, Dordrecht, The Netherlands, Springer. Ishii, Kenichi, 2006. Implications of Mobility: The Uses of Personal Communication Media in Everyday Life. Journal of Communication, 56, 346-365.

Jisa, Harriet, Reilly, Judy. S., Verhoeven, Ludo, Baruch, Elisheva, \& Rosado, Elisa, 2002. Passive voice constructions in written texts: a cross-linguistic developmental study. Written Language and Literacy, 5:2, 163-181.

Kapidzic Sanja \& Herring, Susan C., in press. Gender, Communication, and Self-Presentation in Teen Chatrooms Revisited: Have Patterns Changed? Journal of Computer-Mediated Communication.

Kasesniemi, Eija L., 2003. Mobile messages: Young people and a new communication culture. Tempere, Finland, Tampere University Press.

Kemp, Nenagh, 2011. Mobile technology and literacy: effects across cultures, abilities and the lifespan. Journal of Computer Assisted Learning, 27, 1-3. 
Laursen, Ditte, 2005. Please reply! The replying norm in adolescent SMS communication. In: Harper, R., Palen, L. A. \& Taylor, A. (Eds), The inside text: Social, cultural and design perspectives on SMS, Dordrecht, The Netherlands, Springer.

Leo \& Wolf, 2004. 70\% des 15-35 ans acceptent de recevoir de la publicité sur leur téléphone portable. Retrieved 22 April 2010 from http://www.serialwireless.net/+70-des-15-35ans-acceptent-de,343+.html

Ling, Richard, 2005a. The length of text messages and the use of predictive texting: Who uses it and how much do they have to say? Paper presented at the Association of Internet Researchers, Chicago, IL.

Ling, Richard, 2005b. The socio-linguistics of SMS: An analysis of SMS use by a random sample of Norwegians. In: Ling, R. and Pedersen, P. E. (Eds), Mobile communications: Renegotiation of the social sphere. London, Springer.

McCarthy, Dorothea, 1954. Language development in children. In Mussen, P. (Ed.), Carmichael's manual of child psychology (2nd ed.). New-York, Wiley and Sons.

Noveck, Ira \& Sperber, Dan, 2004. Experimental Pragmatics. Basingstoke, England, Palgrave.

Panckhurst, Rachel, 2009. Short Message Service (SMS): typologie et problématiques futures. In Arnavielle, T. (Ed.), Polyphonies, pour Michelle Lanvin. Université Paul-Valéry, Montpellier 3.

Puustinen, Minna, Bernicot, Josie \& Bert-Erboul, Alain, 2011. Written Computer-Mediated Requests for Help by French-Speaking Students: An Analysis of Their Forms and Functions. Learning and Instruction, 21, 281-289. 
Puustinen, Minna, Volckaert-Legrier, Olga, Coquin, Danièle, \& Bernicot, Josie, 2009. An analysis of students' spontaneous computer-mediated help seeking: A step toward the design of ecologically valid supporting tools. Computers \& Education, 53, 1040-1047

Ravid, Dorit. \& Tolchinsky, Liliana, 2002. Developing linguistic literacy: a comprehensive model. Journal of child language, 29, 2; 417-447.

Reid, Donna, J. \& Reid, Frase, J.M., 2005. Textmates and text Circles: Insights into the Social Ecology of SMS Text messaging. Mobile World Computer Cooperative Work, 2, 105118.

Rettie, Ruth, 2009. Mobile Phone Communication: Extending Goffman to mediated Interaction. Sociology, 43, 3, 421-438.

Rivière, Carole. A., \& Licoppe, Christian, 2005. From voice to text: Continuity and change in the use of mobile phones in France and Japan. In: Harper, R., Palen, L. A. \& Taylor, A. (Eds), The inside text: Social, cultural and design perspectives on SMS, Dordrecht, The Netherlands, Springer.

Rosen, Larry D., Chang, Jennifer, Erwin, Lynne, Carrier, L. Mark \& Cheever, Nancy A., 2010. The Relationship Between "Textisms" and Formal and Informal Writing Among Young Adults. Communication Research, 37, 420-440.

Samsung, 2006. Le comportement mobile belge décortiqué par Samsung. Retrieved 22 April 2009 from http://www.bemobile.be/2006/08/17/le-comportement-mobile-belgedecortique-par-samsung/

Savas, Perihan, 2011. A case study of contextual and individual factors that shape linguistic variation in synchronous text-based computer-mediated communication. Journal of Pragmatics, 43, 298-313. 
Searle, John. R., 1969. Speech acts. Cambridge, MA, Cambridge University Press.

Searle, John. R., \& Vanderveken, Daniel, 1985. Foundations of illocutionnary logic. Cambridge, Cambridge University Press.

Spagnolli, Anna, \& Gamberini, Luciano, 2007. Interacting via SMS: Practices of social closeness and reciprocation. British Journal of Social Psychology 46, 343-364.

Spilioti, Tereza, 2011. Beyond genre: closings and relational work in text-messaging. In: Thurlow , C. and Mroczek, K., (Eds.) Digital discourse: language in the new media (pp. 67-85). New York, U.S.A. : Oxford University Press.

Strömqvist, Sven, E., Johansson, Victoria, Kriz, Sarah, Ragnarsdóttir, Hrafnhildur, Aisenman, Ravid, \& Ravid, Dorit, 2002. Towards a crosslinguistic comparison of lexical quanta in speech and writing. Written Language and Literacy, 5:1, 45-67.

Thurlow, Crispin, 2006. From statistical panic to moral panic: The metadiscursive construction and popular exaggeration of new media language in the print media. Journal of Computer-Mediated Communication, 11:3, 667-701.

Thurlow, Crispin, \& Brown, Alex, 2003. Generation Txt? The sociolinguistics of young people's $\begin{array}{lllll}\text { text-messaging. } & \text { Retrieved } & 28 & \text { July } & 2010 \text { from }\end{array}$ http://faculty.washington.edu/thurlow/papers/Thurlow (2003)-DAOL.pdf

Thurlow, Crispin \& Poff, Michele, in press. The language of text messaging. In: Herring, S.C., Stein, D. \& Virtanen, T. (Eds.), Handbook of the pragmatics of CMC. Berlin and New York, Mouton de Gruyter.

Verschueren, Jeff, 1999. Understanding pragmatics. London: Arnold.

Vignaux, Georges, 2003. Du signe au virtuel: les nouveaux chemins de l'intelligence. Paris : Editions le Seuil. 
Volckaert-Legrier, Olga, 2007. Le courrier électronique chez les adolescents : un nouveau registre de la langue écrite. Thèse de doctorat : Université de Poitiers.

Volckaert-Legrier, Olga, Bernicot, Josie, \& Bert-Erboul, Alain, 2009. Electronic mail, a new written-language register: a study with French-speaking adolescents. British Journal of Developmental Psychology, 27, 163-181.

Waldvogel, Joan, 2007. Greetings and closings in workplace email. Journal of ComputerMediated Communication, 12, 456-477.

Wood, Clare, Jackson, Emma, Hart, L., Plester, Beverly \& Wilde, Lucy, 2011. The effect of text messaging on 9- and 10-year-old children's reading, spelling and phonological processing skills. Journal of Computer Assisted Learning, 27, 28-36. 
Table 1.

Number of Participants by Age, Gender, and SMS Experience Level

\begin{tabular}{lcccc}
\hline Age in years & & $15-16$ & $17-18$ & Total \\
\hline Experienced group & Male & 13 & 15 & 28 \\
& Female & 12 & 20 & 32 \\
& Total Experienced & 25 & 35 & 60 \\
\hline Inexperienced group & Male & 7 & 7 & 14 \\
& Female & 9 & 8 & 17 \\
& Total Inexperienced & $\mathbf{1 6}$ & $\mathbf{1 5}$ & $\mathbf{3 1}$ \\
\hline Total & & $\mathbf{4 1}$ & $\mathbf{5 0}$ & $\mathbf{9 1}$ \\
\hline
\end{tabular}


Table 2.

Number of Participants, Experienced and Inexperienced in SMSing

\section{Experienced participants}

\begin{tabular}{cccc}
\hline & $\begin{array}{c}11 \text { to } 20 \\
\text { messages per } \\
\text { week }\end{array}$ & $\begin{array}{c}21 \text { to } 50 \\
\text { messages per } \\
\text { week }\end{array}$ & $\begin{array}{c}51 \text { to over } 100 \\
\text { messages per } \\
\text { week }\end{array}$ \\
\hline $\begin{array}{c}\text { Number of experienced } \\
\text { participants }\end{array}$ & 33 & 18 & 9 \\
\hline
\end{tabular}

\section{Inexperienced participants}

\section{Less than 5}

messages per

5 to 10 messages per week

week

Number of inexperienced participants 
Table 3.

Number of Messages by Age, Gender, and SMS Experience Level

\begin{tabular}{lcccc}
\hline Age in years & & $15-16$ & $17-18$ & Total \\
& Male & 105 & 224 & 329 \\
& Female & 150 & 178 & 328 \\
& Total Experienced & 255 & 402 & 657 \\
& Male & & & \\
& Female & 22 & 41 & 63 \\
\hline Inexperienced & 50 & 94 & 144 \\
group & Total Inexperienced & 72 & 135 & 207 \\
& & 327 & 537 & 864 \\
\hline Total & & & & \\
\hline
\end{tabular}


Table 4.

Factors and Dependent Variables Used to Analyze Data

Factors

Levels

Age in years $15-16 / 17-18$

Factors $\quad$ Gender Male/female

Experience Experienced/Inexperienced

Dependent variables

\section{Values}

\section{QUANTITY INDEXES}

\begin{tabular}{|c|c|c|}
\hline & $\begin{array}{l}\text { Number of characters } \\
\text { including spaces }\end{array}$ & 1 to 160 (practical maximum) \\
\hline \multicolumn{3}{|l|}{ Dependent } \\
\hline \multirow{2}{*}{ variables } & Number of words & 1 to 42 (observed maximum) \\
\hline & STRUCTURE INDEXES & $\mathrm{M} / \mathrm{O}+\mathrm{M} / \mathrm{M}+\mathrm{C} / \mathrm{O}+\mathrm{M}+\mathrm{C}$ \\
\hline & FUNCTION INDEXES & Informative-transactional/Re \\
\hline
\end{tabular}

Note: Opening: O, Message itself (body of message): $\mathrm{M}$, Closing: $\mathrm{C}$. 
Table 5.

Mean Number of Characters per SMS Message and Mean Number of Words per SMS Message, by Participant Age and Gender

\section{MEAN NUMBER OF CHARACTERS PER SMS MESSAGE}

\begin{tabular}{lccc}
\hline & Total & $15-16$ & $17-18$ \\
\hline Male & $92.23(3.17)$ & $81.75(5.15)$ & $102.71(3.73)$ \\
Female & $120.18(2.27)$ & $129.01(3.58)$ & $111.36(2.80)$ \\
& & & \\
\hline
\end{tabular}

\section{MEAN NUMBER OF WORDS PER SMS MESSAGE}

\begin{tabular}{lccc}
\hline & Total & $15-16$ & $17-18$ \\
\hline Male & $18.51(0.61)$ & $16.32(.99)$ & $20.70(0.71)$ \\
Female & $22.55(0.44)$ & $24.47(0.69)$ & $20.64(0.54)$ \\
& & \\
\hline Note: Standard deviations are shown in parentheses.
\end{tabular}

Note: Standard deviations are shown in parentheses. 
Table 6.

Proportion of Messages for Structures Indexes and Function Indexes

STRUCTURE INDEXES

Proportion of messages with a message-alone structure (M), by participant age, gender, and SMS experience

\begin{tabular}{cccc} 
Male & $\mathbf{0 . 2 7}(\mathbf{0 . 0 3})$ & $\begin{array}{c}\text { Experienced group } \\
\text { Inexperienced group }\end{array}$ & $\begin{array}{c}\mathbf{0 . 2 7}(\mathbf{0 . 0 2}) \\
0.17(0.03)\end{array}$ \\
Female & $0.17(0.02)$ & & $17-18$ \\
Male & & $15-16$ & $0.21(0.03)$ \\
& Experienced group & $\mathbf{0 . 4 4 ( 0 . 0 4 )}$ & $0.29(0.06)$ \\
& Inexperienced group & $0.14(0.09)$ & $0.25(0.03)$ \\
& Total Male & $\mathbf{0 . 2 9 ( 0 . 0 5 )}$ & $0.31(0.03)$ \\
& Experienced group & $0.11(0.03)$ & $0.17(0.04)$ \\
& Inexperienced group & $0.10(0.06)$ & $0.24(0.03)$ \\
\hline
\end{tabular}

Proportion of messages with an "opening-message-closing" structure $(\mathrm{O}+\mathrm{M}+\mathrm{C})$, by participant age, gender and SMS experience

Experienced group $\quad 0.25(0.02)$

Inexperienced group $\quad 0.33(0.03)$

\begin{tabular}{|c|c|c|c|}
\hline \multirow{3}{*}{ Male } & & $15-16$ & $17-18$ \\
\hline & Experienced group & $0.13(0.04)$ & $0.28(0.03)$ \\
\hline & Inexperienced group & $0.36(0.09)$ & $0.24(0.07)$ \\
\hline \multirow[t]{2}{*}{ Female } & Experienced group & $0.36(0.03)$ & $0.20(0.03)$ \\
\hline & Inexperienced group & $0.36(0.06)$ & $0.34(0.04)$ \\
\hline \multicolumn{4}{|c|}{ FUNCTION INDEXES } \\
\hline \multicolumn{4}{|c|}{$\begin{array}{l}\text { Proportion of messages with each function (informative-transactional or relational) in the body of the message, } \\
\text { by participant age, gender, and SMS experience. }\end{array}$} \\
\hline \multirow{2}{*}{$\begin{array}{l}\text { Informative-transactional } \\
\text { Relational }\end{array}$} & $0.54(0.02)$ & & \\
\hline & $0.64(0.02)$ & & \\
\hline \multirow{3}{*}{$\begin{array}{l}\text { Informative-transactional } \\
\text { Relational }\end{array}$} & $15-16$ & $17-18$ & \\
\hline & $0.52(0.03)$ & $0.56(0.02)$ & \\
\hline & $0.71(0.03)$ & $0.57(0.02)$ & \\
\hline \multirow{3}{*}{$\begin{array}{l}\text { Informative-transactional } \\
\text { Relational }\end{array}$} & Male & Female & \\
\hline & $0.58(0.03)$ & $0.50(0.02)$ & \\
\hline & $0.59(0.03)$ & $0.69(0.02)$ & \\
\hline
\end{tabular}

Note: Standard deviations are shown in parentheses, and the highest significant values are indicated in bold print. 
Josie Bernicot is a professor at the University of Poitiers (France). Her research deals with children's language acquisition. In addition to typical and atypical oral language in children, her studies also focus on the use of new communication technologies by adolescents. In France, she has contributed to the development of the pragmatic perspective and the study of the social uses of language. She is the leader of a focus team on this subject at the Cognition and Learning Research Center (CeRCA-CNRS), as well as a member of both the International Pragmatics Association (IPrA) office and the European Journal of Developmental Psychology (EJDP) editorial office.

Olga Vockaert-Legrier received her Ph.D. from the University of Poitiers (France). Currently, she is a lecturer at the University of Toulouse Le Mirail (France) in the department of developmental psychology. Her research focuses on computer mediated communication and its linguistic features, especially email and SMS messages as a new register of written language.

Antonine Goumi received her $\mathrm{PhD}$ in cognitive psychology from the University of Poitiers (France). She began her work as a researcher at the Cognition and Learning Research Center (CeRCA-CNRS) and now works at the National Center for Pedagogical Documentation, under the supervision of the French Ministry of Education. Her research interests are related to technologies for education, the role they play in teaching at school and in the evaluation and improvement of learning.

Alain Bert-Erboul is a researcher at the CNRS (French National Research Agency) and works at the Cognition and Learning Research Center (CeRCA) at the University of Poitiers (France). He collaborates with Josie Bernicot on language developmental research. 